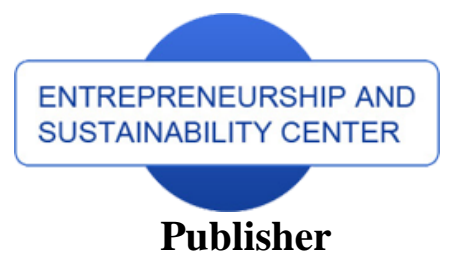

$\underline{\text { http://jssidoi.org/esc/home }}$

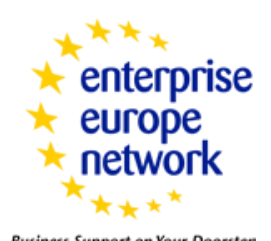

Business Support on Your Doorstep

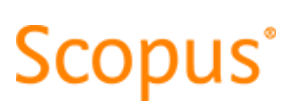

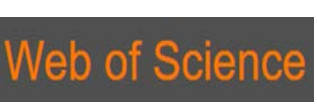

Clarivate
Analytics

\title{
MIGRATION AND THE ECONOMIC CRISIS IN THE EUROPEAN UNION MEMBER STATES: CLUSTER ANALYSIS
}

\author{
Lorena Škuflićc ${ }^{1}$ Mira Krpan², Berislav Žmuk ${ }^{3}$ \\ ${ }^{1,2,3}$ University of Zagreb, Faculty of Economics and Business, Trg J. F. Kennedyja 6, HR-10000 Zagreb, Croatia \\ E-mails: ${ }^{1}$ lskuflic@efzg.hr; ${ }^{2}$ mkrpan@efzg.hr; ${ }^{3}$ bzmuk@efzg.hr
}

Received 18 May 2018; accepted 25 November 2018; published 30 December 2018

\begin{abstract}
European Union (EU) is facing large migration flows, whose distribution and volatility in the observed period between 2006 and 2015 across the EU member states, among other factors, were affected by the financial and economic crisis. This paper examines how the homogeneity of the EU member states was changing with respect to economic performance and migration statistics indicators. Consequently, the non-hierarchical cluster analysis by using k-means method was conducted based on the average values of the selected variables in four time periods: the pre-crisis, crisis, and post-crisis periods. The fourth period is year 2015, the beginning of massive immigration in the EU area due to world migration crisis. Our results indicate relative stability of the number and structure of clusters of EU-28 member states in the selected time periods on the bases of observed variables. There are few exceptions, however, related to countries that were heavily influenced by the financial and economic crisis, and Germany which stood out with decreasing unemployment rates and increasing net migration values in the post-crisis period.
\end{abstract}

Keywords: economic crisis; European Union member states; migration; non-hierarchical cluster analysis

Reference to this paper should be made as follows: Škuflić, L.; Krpan, M.; Žmuk, B. 2018. Migration and the economic crisis in the European Union member states: cluster analysis, Entrepreneurship and Sustainability Issues 6(2): 979-1000. . http://doi.org/10.9770/jesi.2018.6.2(34)

JEL Classifications: C38, E00, F22

\section{Introduction}

European Union (EU) has been hosting growing number of foreign citizens every year. According to Eurostat data, in the period between 2007 and 2015 their number rose by 22.4\% (Eurostat 2017). If observing the available data on the stock of foreign citizens in the pre-crisis period, for example in 2007, around 28.6 million foreign citizens lived in the EU-28 member states, which is approximately 6\% of total population in EU-28 in this period. In Germany (around 7 million or 25\%), Spain (4.5 million or 16\%) and France (3.7 million or 13\%) lived a slightly more than half of all foreign citizens. If the United Kingdom (3.7 million or 13\%) and Italy (2.9 million or $10 \%)$ are added, it can be concluded that five economically largest EU-economies hosted three fourths of all foreign citizens in EU-28 in 2007. Similar conclusion holds for 2015. Around 35 million foreign citizens lived in EU-28 in 2015, which is around 7\% of the total population (Eurostat 2017). According to Eurostat's database, 


\section{The International Journal}

ENTREPRENEURSHIP AND SUSTAINABILITY ISSUES

ISSN 2345-0282 (online) http://jssidoi.org/jesi/

2018 Volume 6 Number 2 (December)

http://doi.org/10.9770/jesi.2018.6.2(34)

Germany hosted the largest number of foreign citizens in EU-28 in 2015 with 7.5 million (22\%), the United Kingdom with 5.4 million (15\%) and Italy with 5 million (14\%) followed. Finally, Spain and France each contributed with around $13 \%$ and $12 \%$, respectively. As can be noticed, the share of foreign citizens in the EU population has increased and their distribution has slightly changed.

Greater volatility is observed, however, when migration flows in the European Union are analysed. The observed period between 2006 and 2015, for which data were available, is very interesting from an economic point of view, since it includes the data for the EU in the pre-crisis period, the data in the period when the EU was struggling with the global financial and economic crisis and the period of the recovery of most EU economies. Furthermore, the world migration crisis in 2015 caused a massive immigration in the EU member states from the Middle East area and Africa. Due to different economic performances of the EU member states which, among other factors, highly influences the size and direction of migration flows, migration flows were very volatile. Some EU countries, which were known as net immigration countries, because of their exceptional economic performances (among other social and political factors) in the pre-crisis period, became net emigration countries, due to increasing emigration and decreasing immigration levels.

On a more general level, the reasons for migrating can be grouped into economic, social and political ones. In this paper we are especially interested in how the homogeneity of the EU member states was changing in the period between 2006 and 2015 with respect to economic performance and migration statistics indicators. The gross domestic product (GDP) per capita was chosen as economic performance proxy, whereas the unemployment rate is used as the labour market performance indicator. The migration statistics indicators are represented by net migration as an indicator of migration flows, and stock of foreign citizens variable as an indicator of migration stock. Consequently, in this paper non-hierarchical cluster analysis by using k-means method with respect to the aforementioned variables in four time periods is conducted. The first period is the pre-crisis period, which includes years 2006 and 2007. The second is the crisis period between 2008 and 2012. The third period refers to the recovery phase and includes years 2013 and 2014. The final period is year 2015, the beginning of massive immigration in the EU area due to world migration crisis. For every time period the cluster analysis is conducted, based on the average values of the selected variables.

The paper is organized as follows. After brief introduction, section 2 gives the literature review. Section 3 explains data and methods. Section 4 gives overview of the European Union economic and migration performances in the period between 2006 and 2015, including descriptive statistics and correlation analysis. Section 5 is devoted to non-hierarchical cluster analysis and interpretation of the results. Section 6 concludes.

\section{Literature review}

The two main objectives of theoretical and empirical research of migration focus on the migrants' decision to leave their country of origin, including the choice of the destination country, and on the economic impacts of migration flows for the destination country (Lincényi 2017; Njaramba et al. 2018; Lietuvnike et al. 2018). The answers to these questions play a crucial role in developing immigration policies for the European countries (Kerr, Kerr 2011).

The human capital model in the mainstream economics implies that international differences in the returns to factor supply, controlling for migration costs, skill levels, income inequality and immigration policies motivate a worker to move (Bodvarsson, Van den Berg 2013). Hicks in 1932 in his Theory of Wages (Hicks 1932) argues that „differences in net economic advantages, chiefly differences in wages, are the main causes of migration“. Borjas' mathematical formalization of Roy model on self-selection in immigration is the theoretical model used in analysing the determinants of immigration and the composition of immigrant flows (Borjas 1999). Mayda (2010) 
The International Journal

ENTREPRENEURSHIP AND SUSTAINABILITY ISSUES

ISSN 2345-0282 (online) http://jssidoi.org/jesi/

2018 Volume 6 Number 2 (December)

http://doi.org/10.9770/jesi.2018.6.2(34)

in her empirical investigation of the determinants of international bilateral migration inflows into fourteen OECD countries by country of origin, between 1980 and 1995, using panel data set, actually tests predictions of a standard international migration model. Among economic determinants of migration flows, Mayda (2010) finds that income opportunities in the destination country significantly increase the size of emigration rates. The share of the young population in the total number of population of the origin country, as a demographic factor, has a positive and significant impact on emigration rates (Mayda 2010). Country's immigration policy plays a very important role in the number and skill distribution of immigrants (Hatton, Williamson 2002). For example, although both the United States and Canada attract large numbers of immigrants, their different immigration policies generate immigrant population that greatly differs in their skill mix (Aydemir, Borjas 2007). Network effects, especially important in providing job information and financial and psychological support to immigrants (Johnson 1980), imply high correlation of bilateral migration flows over time (Clark et al. 2007), which Mayda (2010) also found in her research. Hille and Straubhaar (2001) using pooled time series, cross sectional model of bilateral migration flows between the Southern and Northern EU countries take bilateral rate of migration between emigration and immigration countries in the certain time period as dependent variable, and wage differentials (neoclassical approach), unemployment rates and the distance between countries (human capital approach) and stock of migrants living in the destination country (network migration approach) as independent variables, which are specified in logarithms (Hille and Straubhaar 2001). All estimated coefficients, except the coefficients for distance, have the expected signs and are statistically significant. However, all four coefficients appeared to be jointly significant. Therefore, when analysing determinants of migration flows, the economic, social and institutional variables are taken into account.

The main findings in the extensive literature on the economic impacts of migration, especially its impact on immigrants' and natives' wages and employment, comes down to the overall conclusion that 'the likelihood and magnitude of adverse labour market effects for natives from immigration are substantially weaker than often perceived' (Kerr, Kerr 2011). Naturally, some migrant and native groups are more affected than others, depending on the age, education and duration of migrant's stay.

In recent years, according to the survey of Nathan (2014), attention in the migration literature shifted towards exploring the wider effects of migration on the production and consumption sides of the host country, especially on the entrepreneurship, innovation, investment, prices and public sector, where focus is on the role of highskilled migrants.

Increasing immigration levels in the EU, especially since 2013, importantly contribute to Europe's population growth. Cuaresma et al. (2015) in their quantity and quality perspective of migration, claim that Europe's economic future, among other factors, will by a large amount be influenced by two issues: population ageing and large migration flows. According to United Nations (2017), the size of the total population in Europe would have declined during the period 2000-2015 in the absence of migration. According to European Commission's Eurobarometer report for spring 2015, immigration was the most important issue EU faced in 2015 (European Commission 2015). Consequently, migration issue is seen as one of top priorities at the public and political levels (International Organization for Migration 2017). In addition, it is becoming a first-order policy question in research also (Kerr, Kerr 2011). There is a lot of literature on migration flows and the impact of economic crisis on EU-economies (i.e. Beets, Willekens 2009, Chojnicki, Edo, Rogot 2016), but to our knowledge, there is no paper making the cluster analysis on the EU member states in the pre-crisis, crisis and post-crisis periods. 


\section{Data and methods}

According to the literature review, for the economic and the labour market performance indicators GDP per capita and unemployment rate are chosen. The migration statistics indicators are represented by net migration as an indicator of migration flows, and stock of foreign citizens variable as an indicator of migration stock. Data are collected from Eurostat database (Eurostat 2018a, b, c, d, e, and f) for the EU-28 member states in the period from 2006 to 2015. Data for the variable Stock of foreign citizens are available for the period 2007-2016. In addition, there is no Stock of foreign citizens data for Croatia in the period from 2007 to 2012, for Greece in 2008, for Poland in 2009 and for Romania in the period from 2007 to 2011. Also, there are missing data for Net migration variable. There is no Net migration data for Belgium in 2008 and in 2009, for Bulgaria in 2006 and in the period from 2008 to 2011, for Cyprus in 2008, for Poland in 2008 and for Romania in 2006 and in 2007.

According to Eurostat (2018a, b, c, d, e, f), real GDP per capita is calculated as the ratio of real GDP to the average population of a specific year. The unemployment rate is the number of people unemployed as a percentage of the labour force, where unemployed person is defined according to the guidelines of the International Labour Organization. Unemployed person is someone aged 15 to 74 (in Italy, Spain, the United Kingdom, Iceland and Norway aged 16 to 74 years), without work during the reference week, available to start work within the next two weeks or has already found a job to start within the next three months, and actively having sought employment at some time during the last four weeks. Net migration of a country is the difference between immigration to and emigration from a given area during the year.

The period for which data were available is analysed, which includes the years from 2006 to 2015. Annual growth rate of GDP in real terms in EU-28 economy was used to determine which time period enables the analysis of the economic performance, and as a result the analysis of migration flows, before, during and after the global and financial crisis. In the first defined time period from 2006 and 2007, the average growth rate of GDP for EU-28 economy was 3\% in 2007 compared to the year before. Furthermore, the period of the considerable impact of the global financial and economic crisis on the EU-28 economic output, labour market performance and migration flows includes the years from 2008 to 2012, with the negative growth rate of GDP of the EU-28 economy in 2009 of $4.3 \%$, followed by the recovery in two consecutive years (2010 and 2011), with the growth rates of GDP of $2.1 \%$ and $1.7 \%$, respectively, but then again the EU-28 economy fell by $0.4 \%$ in 2012 . Finally, the third and fourth periods are characterized by the continuous growth of the EU-28 economy, and include the years from 2013 to 2015.

In the first step basic descriptive analysis, along with correlation analysis, is conducted. Afterwards, nonhierarchical cluster analysis by using k-means method will be applied to identify homogeneous groups for the EU member states according to values of the observed variables in selected time periods (Mooi, Sarstedt 2011). 


\section{Overview of the European Union economic and migration performances in the period between 2006 and 2015 - descriptive statistics and correlation analysis}

In the first step, basic descriptive statistics analysis for the four observed variables is conducted and the main results are given in Table 1.

Table 1. Descriptive statistics results of the four observed variables for different observed periods

\begin{tabular}{|c|c|c|c|c|c|}
\hline \multirow[t]{2}{*}{ Period } & \multirow[t]{2}{*}{ Statistics } & \multicolumn{4}{|c|}{ Variable } \\
\hline & & $\begin{array}{l}\text { Real GDP } \\
\text { per capita }\end{array}$ & Net migration & $\begin{array}{c}\text { Stock of } \\
\text { foreign citizens }\end{array}$ & Unemployment rate \\
\hline \multirow{8}{*}{$\begin{array}{c}2006-2007 \\
\text { average }\end{array}$} & $\mathrm{n}$ & 28 & 27 & 26 & 28 \\
\hline & Mean & 24,739 & 64,252 & $1,100,308$ & 7 \\
\hline & Std. dev. & 16,197 & 147,259 & $1,750,853$ & 2 \\
\hline & Coef. var. & 65 & 229 & 159 & 31 \\
\hline & Median & 23,175 & 17,827 & 364,577 & 7 \\
\hline & Skewness & 1.52 & 3.64 & 2.22 & 0.75 \\
\hline & Minimum & 4,700 & $-28,310$ & 13,401 & 4 \\
\hline & Maximum & 81,800 & 714,875 & $7,207,716$ & 12 \\
\hline \multirow{8}{*}{$\begin{array}{c}\text { 2008-2012 } \\
\text { average }\end{array}$} & $\mathrm{n}$ & 28 & 28 & 27 & 28 \\
\hline & Mean & 24,279 & 27,302 & $1,167,578$ & 9 \\
\hline & Std. dev. & 15,538 & 81,797 & $1,824,563$ & 3 \\
\hline & Coef. var. & 64 & 300 & 156 & 37 \\
\hline & Median & 21,610 & 7,526 & 363,409 & 8 \\
\hline & Skewness & 1.51 & 2.60 & 1.95 & 0.95 \\
\hline & Minimum & 5,220 & $-74,707$ & 17,982 & 5 \\
\hline & Maximum & 78,900 & 348,816 & $6,804,369$ & 19 \\
\hline \multirow{8}{*}{$\begin{array}{l}\text { 2013-2014 } \\
\text { average }\end{array}$} & $\mathrm{n}$ & 28 & 28 & 28 & 28 \\
\hline & Mean & 24,411 & 28,947 & $1,197,033$ & 11 \\
\hline & Std. dev. & 15,872 & 116,906 & $1,921,035$ & 5 \\
\hline & Coef. var. & 65 & 404 & 160 & 50 \\
\hline & Median & 19,025 & 2,438 & 348,010 & 9 \\
\hline & Skewness & 1.57 & 2.68 & 1.86 & 1.72 \\
\hline & Minimum & 5,450 & $-173,254$ & 21,901 & 5 \\
\hline & Maximum & 79,300 & 497,029 & $6,829,468$ & 27 \\
\hline \multirow[t]{8}{*}{2015} & $\mathrm{n}$ & 28 & 28 & 28 & 28 \\
\hline & Mean & 25,439 & 67,746 & $1,254,401$ & 10 \\
\hline & Std. dev. & 16,304 & 229,181 & $2,000,596$ & 5 \\
\hline & Coef. var. & 64 & 338 & 159 & 50 \\
\hline & Median & 20,100 & 3,523 & 346,814 & 9 \\
\hline & Skewness & 1.53 & 4.54 & 1.95 & 1.83 \\
\hline & Minimum & 5,800 & $-61,923$ & 22,470 & 5 \\
\hline & Maximum & 81,300 & $1,196,686$ & $7,539,774$ & 25 \\
\hline
\end{tabular}

Source: Authors

According to results presented in Table 1, in the observed period between 2006 and 2015, all observed variables are characterized by large differences in values across EU member states, with the coefficient of variation of above $30 \%$ in all time periods. The average GDP per capita in the EU-28 member states in the period between 2006 and 2015 was around 25 thousand $€$ with slight fluctuations from one period to the next, but with high differences across countries (as expected), with the coefficient of variation of around 64\%.

The lowest value of GDP per capita in 2015 of 5,800 € was recorded in Bulgaria, and the largest of 81,300 $€$ in Luxembourg. Countries that positively stand out in the size of GDP per capita relative to other countries, next to 


\section{The International Journal}

\section{ENTREPRENEURSHIP AND SUSTAINABILITY ISSUES}

ISSN 2345-0282 (online) http://jssidoi.org/jesi/ 2018 Volume 6 Number 2 (December)

http://doi.org/10.9770/jesi.2018.6.2(34)

Luxembourg, are Denmark, Ireland and Sweden. On the other hand, Bulgaria, Romania, Poland, Latvia and Croatia had the lowest GDP per capita in EU-28 in 2015.

The lowest differences between EU countries are visible when unemployment rate in the period 2006-2007 is analysed. This is not surprising since this was the time when all EU member states experienced positive economic growth. Especially high GDP growth rates in the pre-crisis period had Central-Eastern European Union countries. In particular, the Baltic countries grew on average by $9.9 \%$ in 2006 compared to the year before. Due to international exposure, they were also heavily hit by the global financial and economic crisis, resulting in GDP contraction by around $15 \%$ in 2009, but they rapidly recovered. The main reason for the economic prosperity of Central-Eastern European Union countries was a strong reliance on foreign capital, with two trajectories of capital development distinguished (Avlijas 2017). The Baltic countries encourage the high value service sectors, such as banking and real estate (Bohle, Greskovits 2012), while the Czech Republic, Hungary, Poland and Slovakia rest mostly on the industry sector, producing higher value manufacturing products (Stockhammer et al. 2016).

The average unemployment rate in the EU-28 in the period 2006-2007 was 7\%. The highest income EUeconomies (measured by GDP per capita), Denmark (3.9\%), Ireland (4.6\%), Luxembourg (4.4\%), the Netherlands (4.6\%) and Austria (5.1\%) recorded the lowest average unemployment rates in this period. On the other hand, new EU member states: Slovakia (12.45\%), Poland (11.8\%) and Croatia (10.8\%) recorded the highest average unemployment rates in the period 2006-2007.

When the migration flows in the observed period are analysed, the total number of immigrants into the EU area increased by around 13\% in 2007 compared to the previous year, but the trend reversed in the period between 2007 and 2009. Since 2010, the number of immigrants has started to rise, whereby the rise in the period between 2010 and 2013 was very modest, by 5\%. In the period from 2013 and 2015 the number of immigrants in the EU member states rose by 37\%, from 3.4 million to 4.6 million. When emigration is concerned, 2.8 million people emigrated from the EU-28 in 2015. The number of emigrants shows an upward trend since 2009, with slight fluctuations. Therefore, net migration since 2013 more than tripled and was equal to 1.9 million people in 2015.

The highest variability across countries is noticed when the variable Net migration, next to the variable Stock of foreign citizens, is concerned. In the period between 2006 and 2007 Spain was the leading EU immigration country. It was the time when Spain enjoyed continuous economic growth, reaching $4.2 \%$ in 2006 and $3.8 \%$ in 2007. In 2006841 thousand, and in 2007968 thousand immigrants entered Spain, causing, among other factors, higher rate of demographic growth. Spain was the leading immigration country up until 2008. Very high immigration levels of around 900 thousand and relatively low emigration levels caused the highest positive net migration values of about 700 thousand in 2006 and 2007. Germany followed Spain with high levels of immigration of around 670 thousand. At the same time, many people emigrated from Germany, which resulted in low but positive levels of net migration and put Germany on the last place among the top five economically largest EU countries according to the values of net migration in this period (other countries in decreasing order of magnitude were Italy, United Kingdom and France in the period 2006-2007).

As it was already mentioned, in 2007, the largest number of foreign citizens lived in the strongest EU economies, Germany, Spain, France, United Kingdom and Italy. On the other hand, Malta (13.4 thousand), Bulgaria (25.5 thousand) and Slovakia (32.1 thousand) recorded the lowest number of foreign citizens in 2007.

In 2009, due to global economic and financial crisis, the average GDP in EU-28 decreased by 4.3\% compared to the year before. All countries except Poland faced negative growth rates in 2009. This was the time when the Polish economy was enjoying high investment rates, which resulted in rapid capital accumulation. One of the sources of investment funding was "inflow of structural funds from the EU". On the other hand, low productivity labour force was replaced by more productive workers (Gradzewicz et al. 2014). 
Due to severe global economic crisis, from the period 2006-2007 to the period 2013-2015 period the average EU28 unemployment rate rose by $43 \%$. An interesting fact is that the variability across countries with respect to unemployment rate increased by 60\% from the 2006-2007 to the 2013-2015 period. On one side, there were Germany (4.6\%), the Czech Republic (5.1\%) and the United Kingdom (5.3\%) that recorded the lowest unemployment rates in 2015, whereas Greece (24.9\%) and Spain (22.1\%) were struggling with the highest unemployment rate in 2015 (although the situation was even worse in 2013 on the Greek and Spanish labour market).

Among the Central EU countries (the Czech Republic, Hungary, Poland and Slovakia), Poland has been recording the highest negative net migration values in the EU since 2007, reaching the highest value in 2011, of 109 thousand people. Immigration levels were relatively high and increasing, especially since 2009, when Poland adjusted its immigration policy to become more open to immigrants, especially those "needed by the Polish economy”, (Dąbrowski et al. 2014). At the same time, emigration levels recorded even higher values, especially after Polish accession into the EU in 2004. It is therefore not surprising that Poland is called an immigration and emigration country.

The EU enlargement in 2004 affected migration flows in Baltic countries, resulting in massive emigration (Hazans 2016). According to the data in the observed period from 2006 to 2015, Latvia was experiencing large emigration flows. A major increase in emigration levels is especially evident after the beginning of economic crisis in 2008, when the number of emigrants suddenly increased by $75 \%$ compared to the year before (from 15,463 in 2007 to 27,045 in 2008). This trend continued up until 2011. This is not surprising, since the Baltic countries were experiencing the largest GDP drop, by 15\% in 2009 compared to the year before. Consequently, unemployment rates rose sharply in all three Baltic countries, from 5.5\% in 2008 to $13.5 \%$ in 2009 and $16.7 \%$ in 2010 in Estonia, from $7.7 \%$ in 2008 to $17.5 \%$ in 2009 and 19.5\% in 2010 in Latvia, and from 5.8\% in 2008 to 13.8\% in 2009 and 17.8\% in 2010 in Lithuania. The following years were characterized by positive growth rates and falling unemployment rates, with year 2015 ending with the unemployment rate of $6.2 \%$ in Estonia, 9.9\% in Latvia and 9.1\% in Lithuania.

It is interesting to note how outliers at the variable Net migration changed in the observed period. In the pre-crisis period, up to 2007, Spain was on the top of European Union's countries of immigration. With the global financial and economic crisis, migration flows changed. Spain was recording high GDP contractions and increasing unemployment rates, which resulted in decreasing levels of immigration and increasing levels of emigration. Consequently, Spain became net emigration country. In the period 2008-2012 Italy stood out as the country with the highest net migration of 349 thousand. Since 2012 Germany took the first place, deviating with almost 5 standard deviations from the mean net migration in 2015. The detailed results are given in Table 2. 
The International Journal

ENTREPRENEURSHIP AND SUSTAINABILITY ISSUES

ISSN 2345-0282 (online) http://jssidoi.org/jesi/

2018 Volume 6 Number 2 (December)

http://doi.org/10.9770/jesi.2018.6.2(34)

Table 2. Standardized values of variables (z-scores), the top three and the last three European Union member states

\begin{tabular}{|c|c|c|c|c|c|}
\hline \multirow[t]{2}{*}{ Period } & \multirow[t]{2}{*}{ Variable } & \multicolumn{2}{|c|}{ Top three } & \multicolumn{2}{|c|}{ Last three } \\
\hline & & Member state & z-score & Member state & z-score \\
\hline \multirow{12}{*}{$\begin{array}{c}\text { 2006-2007 } \\
\text { average }\end{array}$} & \multirow[t]{3}{*}{ Real GDP per capita } & Luxembourg & 3.52 & Bulgaria & -1.24 \\
\hline & & Denmark & 1.32 & Romania & -1.17 \\
\hline & & Ireland & 0.97 & Poland & -1.02 \\
\hline & \multirow[t]{3}{*}{ Net migration } & Spain & 4.42 & Poland & -0.63 \\
\hline & & Italy & 1.93 & Lithuania & -0.59 \\
\hline & & United Kingdom & 0.82 & Latvia & -0.49 \\
\hline & \multirow[t]{3}{*}{ Stock of foreign citizens } & Germany & 3.49 & Malta & -0.62 \\
\hline & & Spain & 1.91 & Bulgaria & -0.61 \\
\hline & & France & 1.48 & Slovakia & -0.61 \\
\hline & \multirow[t]{3}{*}{ Unemployment rate } & Slovakia & 2.42 & Denmark & -1.43 \\
\hline & & Poland & 2.15 & Cyprus & -1.25 \\
\hline & & Croatia & 1.70 & Luxembourg & -1.19 \\
\hline \multirow{12}{*}{$\begin{array}{c}\text { 2008-2012 } \\
\text { average }\end{array}$} & \multirow[t]{3}{*}{ Real GDP per capita } & Luxembourg & 3.52 & Bulgaria & -1.23 \\
\hline & & Denmark & 1.28 & Romania & -1.15 \\
\hline & & Sweden & 0.97 & Latvia & -0.97 \\
\hline & \multirow[t]{3}{*}{ Net migration } & Italy & 3.93 & Romania & -1.25 \\
\hline & & United Kingdom & 2.12 & Poland & -1.16 \\
\hline & & Germany & 1.50 & Lithuania & -0.79 \\
\hline & \multirow[t]{3}{*}{ Stock of foreign citizens } & Germany & 3.09 & Malta & -0.63 \\
\hline & & Spain & 2.26 & Lithuania & -0.62 \\
\hline & & United Kingdom & 1.79 & Romania & -0.62 \\
\hline & \multirow[t]{3}{*}{ Unemployment rate } & Spain & 2.82 & Austria & -1.31 \\
\hline & & Latvia & 1.70 & Netherlands & -1.30 \\
\hline & & Greece & 1.51 & Luxembourg & -1.26 \\
\hline \multirow{12}{*}{$\begin{array}{c}\text { 2013-2014 } \\
\text { average }\end{array}$} & \multirow[t]{3}{*}{ GDP per capita } & Luxembourg & 3.46 & Bulgaria & -1.19 \\
\hline & & Denmark & 1.28 & Romania & -1.11 \\
\hline & & Sweden & 0.99 & Latvia & -0.90 \\
\hline & \multirow[t]{3}{*}{ Net migration } & Germany & 4.00 & Spain & -1.73 \\
\hline & & United Kingdom & 1.99 & Greece & -0.70 \\
\hline & & Italy & 1.13 & Poland & -0.68 \\
\hline & \multirow[t]{3}{*}{ Stock of foreign citizens } & Germany & 2.93 & Lithuania & -0.61 \\
\hline & & United Kingdom & 1.99 & Malta & -0.61 \\
\hline & & Spain & 1.91 & Croatia & -0.61 \\
\hline & \multirow[t]{3}{*}{ Unemployment rate } & Greece & 2.99 & Germany & -1.05 \\
\hline & & Spain & 2.67 & Austria & -0.98 \\
\hline & & Croatia & 1.20 & Luxembourg & -0.90 \\
\hline \multirow[t]{12}{*}{2015} & \multirow[t]{3}{*}{ Real GDP per capita } & Luxembourg & 3.43 & Bulgaria & -1.20 \\
\hline & & Ireland & 1.59 & Romania & -1.11 \\
\hline & & Denmark & 1.22 & Croatia & -0.91 \\
\hline & Net migration & Germany & 4.93 & Romania & -0.57 \\
\hline & & United Kingdom & 1.15 & Greece & -0.49 \\
\hline & & Italy & 0.29 & Poland & -0.47 \\
\hline & Stock of foreign citizens & Germany & 3.14 & Lithuania & -0.62 \\
\hline & & United Kingdom & 2.08 & Malta & -0.61 \\
\hline & & Italy & 1.88 & Croatia & -0.61 \\
\hline & Unemployment rate & Greece & 3.19 & Germany & -1.05 \\
\hline & & Spain & 2.60 & Czech Republic & -0.94 \\
\hline & & Croatia & 1.35 & United Kingdom & -0.90 \\
\hline
\end{tabular}

Source: Authors 
The International Journal

ENTREPRENEURSHIP AND SUSTAINABILITY ISSUES

ISSN 2345-0282 (online) http://jssidoi.org/jesi/

2018 Volume 6 Number 2 (December)

http://doi.org/10.9770/jesi.2018.6.2(34)

Table 3 contains correlation matrices for the observed variables in the four observed periods. Due to some missing data, number of included EU member states is not the same in all observed periods. Casewise deletion approach was applied. In other words, if there is a missing data at any of the observed variable, such EU member state was omitted from the analysis.

Table 3. Correlation matrices, $n=26$ for $2006-2007$ period average, $n=27$ for $2008-2012$ period average, $n=28$ for $2013-2014$ period average and for 2015

\begin{tabular}{|c|c|c|c|c|c|}
\hline \multirow[t]{2}{*}{ Period } & \multirow[t]{2}{*}{ Statistics } & \multicolumn{4}{|c|}{ Variable } \\
\hline & & GDP per capita & Net migration & Stock of foreign citizens & Unemployment rate \\
\hline \multirow{4}{*}{$\begin{array}{c}\text { 2006-2007 } \\
\text { average }\end{array}$} & GDP per capita & 1.0000 & & & \\
\hline & Net migration & 0.0708 & 1.0000 & & \\
\hline & Stock of foreign citiz. & 0.1415 & $0.5521 * * *$ & 1.0000 & \\
\hline & Unemployment rate & $-0.4389 * *$ & 0.0590 & 0.2063 & 1.0000 \\
\hline \multirow{4}{*}{$\begin{array}{c}\text { 2008-2012 } \\
\text { average }\end{array}$} & GDP per capita & 1.0000 & & & \\
\hline & Net migration & 0.2525 & 1.0000 & & \\
\hline & Stock of foreign citiz. & 0.1724 & $0.6558 * * *$ & 1.0000 & \\
\hline & Unemployment rate & $-0.4261 * *$ & -0.2050 & 0.1229 & 1.0000 \\
\hline \multirow{4}{*}{$\begin{array}{c}\text { 2013-2014 } \\
\text { average }\end{array}$} & GDP per capita & 1.0000 & & & \\
\hline & Net migration & 0.2504 & 1.0000 & & \\
\hline & Stock of foreign citiz. & 0.1975 & $0.6521 * * *$ & 1.0000 & \\
\hline & Unemployment rate & $-0.3280 *$ & $-0.4692 * *$ & 0.0567 & 1.0000 \\
\hline \multirow[t]{4}{*}{2015} & GDP per capita & 1.0000 & & & \\
\hline & Net migration & 0.1982 & 1.0000 & & \\
\hline & Stock of foreign citiz. & 0.1855 & $0.7522 * * *$ & 1.0000 & \\
\hline & Unemployment rate & -0.2359 & -0.2839 & 0.0305 & 1.0000 \\
\hline
\end{tabular}

Note: * Statistically significant correlation at $10 \%$. ** Statistically significant correlation at $5 \% . * * *$ Statistically significant correlation at $1 \%$.

Source: Authors, Statistica 13.3

Correlation between the variable net migration and the variable stock of foreign citizens is highly statistically significant in all the observed periods, and there is positive and moderate to strong relationship between these variables. Furthermore, statistically significant correlation exists also between real GDP per capita and unemployment rate in the periods 2006-2007 and 2008-2012, with the relationship being negative and moderate. A similar correlation also exists between net migration and unemployment rate.

\section{Non-hierarchical cluster analysis}

For the application of cluster methods, it is recommended to have at least $2^{\mathrm{k}}$ units, where $\mathrm{k}$ stands for the number of variables used in clustering (Formann 1984). In this paper four variables are selected. Consequently, the minimum number of units for cluster analysis is 16, which is fulfilled since objects of our analysis are EU-28 member states.

Before the cluster analysis is conducted, variable data are linearly transformed into a specific range in order to obtain clusters of good quality (Mohamad, Usman 2013). K-means approach as the most computationally efficient and the most widespread (Dolnicar 2002) non-hierarchical (partitional) cluster analysis method is chosen. In the k-means approach the iterative process of relocating units between clusters according to their vicinity to cluster means is conducted. The maximum average distance method was used to form initial approximations (Lee, Han 2012). As a distance measure squared Euclidean distances are used, with more weight given to EU member states that are away from cluster mean (Bora, Gupta 2014). 
However, in non-hierarchical cluster analysis the number of clusters should be determined in advance. Therefore, in this article the optimum number of clusters will be found by using the v-fold cross-validation approach (Thomassey, Fiordaliso 2006). In this approach, values of variables are first divided into v subsamples. Afterwards, subsamples are gradually dropped out from the analysis, estimates for omitted subsamples are calculated and resulting errors are summed across all subsamples. Solution with the smallest overall error is used to select the optimum number of clusters (De'ath, Fabricius 2000). The optimum number of clusters is illustrated by the cost sequence graph, on which the error function values for different number of clusters is shown (Tibshirani et al. 2001). We decide that the optimum number of clusters, marked with $\mathrm{x}$, is determined by the criterion that the decrease of error function for solution of $x+1$ clusters is not lower than $5 \%$.

In Figure A1, given in Appendix, graphs of the cost sequence for different observed periods are presented. Graphs of the cost sequence are used to determine the optimal number of clusters in each observed period. Therefore, the optimal number of clusters is 3 in the periods 2006-2007 and 2008-2012, and 5 in the periods 2013-2014 and in 2015.

Table 4. Selected results from ANOVA tables for different observed periods, k means clustering

\begin{tabular}{|c|c|c|c|c|}
\hline \multirow[t]{2}{*}{ Period } & \multirow[t]{2}{*}{ Number of clusters } & \multirow[t]{2}{*}{ Variable } & \multicolumn{2}{|c|}{ Statistics } \\
\hline & & & F-value & $p$-value \\
\hline \multirow{4}{*}{$\begin{array}{l}\text { 2006-2007 } \\
\text { average }\end{array}$} & \multirow[t]{4}{*}{3} & GDP per capita & 13.468 & 0.0001 \\
\hline & & Net migration & 9.997 & 0.0008 \\
\hline & & Stock of foreign citizens & 60.885 & $<0.0001$ \\
\hline & & Unemployment rate & 6.185 & 0.0071 \\
\hline \multirow{4}{*}{$\begin{array}{c}\text { 2008-2012 } \\
\text { average }\end{array}$} & \multirow[t]{4}{*}{3} & GDP per capita & 4.470 & 0.0224 \\
\hline & & Net migration & 21.898 & $<0.0001$ \\
\hline & & Stock of foreign citizens & 22.695 & $<0.0001$ \\
\hline & & Unemployment rate & 27.275 & $<0.0001$ \\
\hline \multirow{4}{*}{$\begin{array}{c}\text { 2013-2014 } \\
\text { average }\end{array}$} & \multirow[t]{4}{*}{5} & GDP per capita & 15.476 & $<0.0001$ \\
\hline & & Net migration & 51.737 & $<0.0001$ \\
\hline & & Stock of foreign citizens & 54.048 & $<0.0001$ \\
\hline & & Unemployment rate & 15.412 & $<0.0001$ \\
\hline \multirow[t]{4}{*}{2015} & \multirow[t]{4}{*}{5} & GDP per capita & 15.460 & $<0.0001$ \\
\hline & & Net migration & 149.067 & $<0.0001$ \\
\hline & & Stock of foreign citizens & 70.452 & $<0.0001$ \\
\hline & & Unemployment rate & 13.186 & $<0.0001$ \\
\hline
\end{tabular}

Source: Authors, Statistica 13.3

Selected results from ANOVA tables for all four observed periods are provided in Table 4. Null hypothesis, that cluster means are equal, at the significance level of $5 \%$ can be rejected at all variables in all observed periods. Therefore, the clustering process was successful in clustering the EU member states according to the observed variable values in the observed periods.

For better comparison of clusters and understanding of the relationship between them, variable means in each cluster are normalized and their graphs are represented in Figure A2, given in Appendix, for all observed time periods. 


\subsection{Non-hierarchical cluster analysis in the period 2006-2007}

Table 5 delivers the cluster results for the pre-crisis period, with respect to the selected variable values. Croatia and Romania are left out of the cluster analysis for this period due to missing data. Therefore, 26 countries are clustered, and are grouped into three clusters. The structure of the clustering process in all time period can be found in Appendix in Table A1.

Table 5. Cluster means, k-means clustering, $k=3$ clusters, $h=4$ variables, $n=26$ European Union member states, 2006 -2007 average

\begin{tabular}{|c|c|c|c|c|c|c|}
\hline \multirow[t]{2}{*}{ Cluster } & \multirow{2}{*}{$\begin{array}{c}\text { No. of EU } \\
\text { member states }\end{array}$} & \multirow{2}{*}{$\begin{array}{c}\% \text { of EU } \\
\text { member states }\end{array}$} & \multicolumn{4}{|c|}{ Variables } \\
\hline & & & GDP per capita & Net migration & Stock of foreign citizens & Unemployment rate \\
\hline 1 & 7 & 26.92 & 43,671 & 30,497 & 422,325 & 4.77 \\
\hline 2 & 5 & 19.23 & 29,290 & 274,820 & $4,388,303$ & 7.57 \\
\hline
\end{tabular}

Source: Authors, Statistica 13.3

According to the results, Cluster 1 consists of seven EU member states, which makes 27\% of all EU member states. It consists of Austria, Cyprus, Denmark, Ireland, Luxembourg, the Netherlands and Sweden. These countries, in comparison to the other two clusters, had the highest average real GDP per capita of 43.7 thousand $€$ and the lowest average unemployment rate of $4.8 \%$ in the period 2006-2007. These are the countries that are very attractive to foreign citizens, recording positive average net migration values (of 30.5 thousand) and the average stock of foreign citizens of 422.3 thousand. Denmark, known for its dynamic labour market, is the EU country with the lowest average unemployment rate in this period (3.9\%). Luxembourg naturally distinguishes itself from the rest of the group with the highest level of income, with an average GDP per capita of 81.8 thousand $€$. Ireland recorded the highest positive value of net migration in this period (84.7 thousand). It was the time when the Irish economy rose by 5.2\% in 2007 compared to the year before. The highest stock of foreign citizens was recorded in Austria, with approximately 800 thousand of foreign citizens. The Netherlands with approximately 600 thousand and Ireland with approximately 500 thousand followed.

It is surprising that Finland and Belgium, as countries with very high levels of GDP per capita are not in the first cluster. Belgium recorded one of the highest levels of net migration in period 2006-2007 of 52.5 thousand, after Spain, Italy, the United Kingdom, France, Ireland and Sweden and fifth largest average stock of foreign citizens of 952 thousand. Taking a look at the data for the unemployment rates in Belgium and Finland in the period from 2006 to 2007, they are well above the average unemployment rate of the countries making the first cluster, which is $4.8 \%$. The average unemployment rate in the observed period in Finland was $7.3 \%$ and in Belgium it was even higher, $7.9 \%$. The average unemployment rate in Sweden, for example, as a member of the first cluster was also above the average unemployment rate of the members of its cluster, 6.6\%, but Sweden has much higher values of net migration and of the stock of foreign citizens than Finland. Sweden recorded sixth highest average value of net migration in this period, 52.5 thousand and Finland much lower, 12 thousand. Sweden hosted four times more of foreign citizens in the period 2006-2007 than Finland, of 472 thousand.

The second cluster in the period 2006-2007 is made up of five economically strongest economies, according to the nominal GDP, and consequently, the most attractive EU countries to migrants: Germany, France, the United Kingdom, Italy and Spain. Their average GDP per capita was 29.3 thousand $€$ and the average unemployment rate was 7.6\%, above the average EU-28 unemployment rate in this period. These are countries with the highest positive net migration, whose average value was 275 thousand people and an average of 4.4 million foreign citizens lived in these countries in the period 2006-07. Spain recorded the highest average net migration, of 715 thousand. Italy, the United Kingdom, France and Germany followed. 
The International Journal

ENTREPRENEURSHIP AND SUSTAINABILITY ISSUES

ISSN 2345-0282 (online) http://jssidoi.org/jesi/

2018 Volume 6 Number 2 (December)

http://doi.org/10.9770/jesi.2018.6.2(34)

The third cluster consists of 14 EU member states, which makes 54\% of all EU member state: Belgium, Bulgaria, the Czech Republic, Estonia, Finland, Greece, Hungary, Lithuania, Latvia, Malta, Poland, Portugal, Slovakia and Slovenia. The majority of the members are countries that later joined the EU in the process of its enlargement. The main characteristic of these countries is that, in comparison to the other two clusters, their average GDP per capita was the lowest in the EU, 15,982€. The same conclusion holds for Net migration and Stock of foreign citizens' averages. The average net migration was low, but positive. Only Bulgaria, Lithuania and Poland recorded negative net migration in this period. The average unemployment rate was however the highest in the EU, 7.7\%, actually very similar to the members of the second cluster.

\subsection{Non-hierarchical cluster analysis in the period 2008-2012}

Table 6 contains the results of conducted clustering by taking into account 2008-2012 period. This period includes the year 2009, when the EU economy due to global economic and financial crisis fell by $4.3 \%$ compared to the year before. The negative growth rate was also recorded in 2012, when the EU economy on average fell by $0.4 \%$, compared to the previous year.

Table 6. Cluster means, k-means clustering, $\mathrm{k}=3$ clusters, $\mathrm{h}=4$ variables, $\mathrm{n}=27$ European Union member states, 2008 -2012 average

\begin{tabular}{|c|c|c|c|c|c|c|}
\hline \multirow[t]{2}{*}{ Cluster } & \multirow{2}{*}{$\begin{array}{c}\text { No. of EU } \\
\text { member states }\end{array}$} & \multirow{2}{*}{$\begin{array}{c}\% \text { of EU } \\
\text { member states }\end{array}$} & \multicolumn{4}{|c|}{ Variables } \\
\hline & & & GDP per capita & Net migration & Stock of foreign citizens & Unemployment rate \\
\hline 2 & 4 & 14.81 & 29,980 & 186,188 & $4,683,638$ & 7.85 \\
\hline
\end{tabular}

Source: Authors, Statistica 13.3

The EU member states are unevenly distributed across three clusters. However, compared to 2006-2007 period, there are some major changes in the structure of clusters. Spain left the second cluster and joined the third. Ireland left the first cluster and joined the third. Belgium, the Czech Republic, Finland, Malta and Slovenia left the third cluster and joined the first cluster. The explanations for such changes in the structure of clusters will be given below.

The first cluster consists of 11 member states: Austria, Cyprus, Denmark, Luxembourg, the Netherlands and Sweden (old) and Belgium, the Czech Republic, Finland, Slovenia, Romania (new). Members of the first cluster had the highest average GDP per capita, 32 thousand $€$. Now the difference is not so large compared to the second cluster. This is due to entrance of new members, such as Slovenia and the Czech Republic, which have below EU average GDP per capita values. These are the countries with the lowest average unemployment rate, of $6.5 \%$ in this period in this group. New members of this cluster had below EU average unemployment rates in the period of global and financial crisis. These countries were usually recording positive net migration values, but there are some exceptions. For example, the migration flows were very volatile in the Czech Republic. In 2007 compared to the year before, the number of immigrants rose by 59\% to 105 thousand people, and the number of emigrants fell by 39\% to 20.5 thousand people, which resulted in increasing net migration values from 35 thousand in 2006 to 84 thousand in 2007. But the following years were characterized by a massive emigration, where the number of emigrants rose by $151 \%$ in 2008 compared to the year before. In the period between 2009 and 2011 immigration level fell from 108 thousand to 27 thousand. Consequently, net migration values fell from 13.8 thousand to -28.8 thousand. Since 2011, emigration levels have been decreasing and immigration levels increasing and the net migration was positive in 2015. Romania, following Bulgaria, has the lowest GDP per capita in the EU and recorded large negative net migration values in the period between 2008 and 2011. In 2008 Romania recorded the 


\section{The International Journal}

\section{ENTREPRENEURSHIP AND SUSTAINABILITY ISSUES}

ISSN 2345-0282 (online) http://jssidoi.org/jesi/ 2018 Volume 6 Number 2 (December)

http://doi.org/10.9770/jesi.2018.6.2(34)

third highest emigration level, 302.8 thousand (after Germany and the United Kingdom) and ended 2008 with the net migration value of -164 thousand. It had very low, below EU-28 average unemployment rate of $6.6 \%$ in this period.

The second cluster is again reserved for the four economically strongest EU economies, Germany, France, Italy and the United Kingdom. Compared to the previous period, Spain left the cluster and joined the third. Unlike Italy, France and the United Kingdom, Germany stood out with decreasing unemployment rate in this period, from $7.4 \%$ in 2008 to $5.4 \%$ in 2012. The average net migration and the average stock of foreign citizens for the members of the second cluster were the largest in EU. But in 2008 the net migration for Germany was negative, 56 thousand. This was not in accordance with the assumption of the population projection made in this period, which was based on the assumption that Germany will have an annual net migration of 100 thousand starting in 2008 (Süssmuth 2009). In the light of low fertility rates, better life expectancy and consequently high proportion of older population in German society (65 or older) by 2030 the German population was expected to decrease by $6.4 \%$ (by 5 million people), where 30\% of population will be 65 or older (Süssmuth 2009). In 2008 GDP rose by $1.1 \%$ compared to the year before and contracted by $4.9 \%$ in 2009. Since 2009 immigration to Germany has started to rise. The highest rise was recorded in 2015. At the same time, emigration was slowing down, which resulted in continuous rise in the net migration values.

The third cluster in the period 2008-2012 consists of 11 EU-member states: Bulgaria, Estonia, Greece, Hungary, Ireland, Lithuania, Latvia, Poland, Portugal, Slovakia and Spain. Unlike the pre-crisis period, Belgium, the Czech Republic, Finland, Malta and Slovenia joined the first cluster, while Spain and Ireland joined this cluster. The third cluster is made of countries with the lowest average GDP per capita of 15 thousand $€$, the highest average unemployment rate of $12.7 \%$ and negative average net migration values of -12 thousand. The average stock of foreign citizens is relatively high, of 744 thousand, mainly due to inclusion of Greece and Spain.

The reason why Spain joined this cluster lies in its negative growth rates from 2009 to 2013, rising unemployment rates, from $11.3 \%$ in 2008 to 26\% in 2013, which made Spain net emigration country. Spanish foreign workers were usually unskilled and inexperienced and worked in sectors where the local labour supply was scarce, and these are labour-intensive sectors. Domínguez-Mujica et al. (2012) estimate that immigrants contributed to a 40 per cent increase in GDP between 2001 and 2006. On the other hand, due to low-cost foreign labour, labour productivity remained low, since firms didn't have an incentive to replace low-cost foreign labour force by capital, (Domínguez-Mujica et al. 2012). Economic crisis had a major impact on the employment of foreign citizens, reducing it dramatically by $11 \%$ in 2009 compared to the year before, increasing the share of unemployed foreign citizens in the total number of active foreign citizens from $12.2 \%$ in 2007 to 37\% in 2013 (Eurostat 2017). To restrict the arrival of new immigrants, the Spanish government reduced the work permits quotas and modified the Foreign Residents Law with the goal of toughening residence permit requirements (Domínguez-Mujica et al. 2012). The number of immigrants was continuously decreasing between 2008 and 2013, from 600 thousand in 2008 to 280.7 thousand in 2013, with a slight increase in 2011. At the same time, emigration was increasing, causing continuous fall of net migration values, reaching -251,531 in 2013 (net migration was 731 thousand in 2007) (Eurostat 2017).

Unlike the pre-crisis period, the Celtic Tiger era, when Ireland was recording high positive values of net migration, of 95 thousand people in 2006, when the Irish economy rose on average above 5\% in the period between 2006 and 2007, and when Ireland was in the group of EU countries with the lowest unemployment rate of 4.6\% (with Luxembourg), situation changed since 2007. In 2009 compared to 2007, the number of immigrants decreased by $60 \%$, from 122.4 thousand in 2007 to 50.1 thousand in 2009. At the same time, the number of emigrants was continuously increasing up until 2012, which resulted in negative and increasing net migration values. Net migration in 2012 in Ireland was negative and equal to -35 thousand people. The global financial and 
economic crisis caused a sharp increase in unemployment rate to 14.7\% in 2011 and 2012. In 2008 GDP declined by $3.9 \%$ compared to the year before and even more in 2009 , by $4.6 \%$ compared to the year before.

\subsection{Non-hierarchical cluster analysis in the period 2013-2014 and in 2015}

The clustering process in the period 2013-2014 and in 2015 classified 28 EU-Member States in five clusters and gave the same structure of clusters. The characteristics of each cluster can be found in Table 7 and Table 8.

Table 7. Cluster means, k-means clustering, $k=5$ clusters, $h=4$ variables, $n=28$ European Union member states, 2013-2014 average

\begin{tabular}{|c|c|c|c|c|c|c|}
\hline \multirow[t]{2}{*}{ Cluster } & \multirow{2}{*}{$\begin{array}{c}\text { No. of EU } \\
\text { member states }\end{array}$} & \multirow{2}{*}{$\begin{array}{c}\% \text { of EU } \\
\text { member states }\end{array}$} & \multicolumn{4}{|c|}{ Variables } \\
\hline & & & GDP per capita & Net migration & Stock of foreign citizens & Unemployment rate \\
\hline 2 & 14 & 50.00 & 12,689 & $-10,051$ & 150,265 & 10.94 \\
\hline 4 & 2 & 7.14 & 19,500 & $-113,362$ & $2,872,797$ & 26.15 \\
\hline 5 & 8 & 28.57 & 43,238 & 25,317 & 628,770 & 7.83 \\
\hline
\end{tabular}

Source: Authors, Statistica 13.3

Table 8. Cluster means, k-means clustering, k=5 clusters, h=4 variables, n=28 European Union member states, 2015.

\begin{tabular}{|c|c|c|c|c|c|c|}
\hline \multirow[t]{2}{*}{ Cluster } & \multirow{2}{*}{$\begin{array}{c}\text { No. of EU } \\
\text { member states }\end{array}$} & \multirow{2}{*}{$\begin{array}{c}\% \text { of EU } \\
\text { member states }\end{array}$} & \multicolumn{4}{|c|}{ Variables } \\
\hline & & & GDP per capita & Net migration & Stock of foreign citizens & Unemployment rate \\
\hline 2 & 3 & 10.71 & 29,500 & 177,097 & $4,932,230$ & 9.20 \\
\hline 4 & 2 & 7.14 & 20,100 & $-23,333$ & $2,638,162$ & 23.50 \\
\hline 5 & 8 & 28.57 & 45,375 & 44,581 & 669,868 & 7.50 \\
\hline
\end{tabular}

Source: Authors, Statistica 13.3

This was the period in which the majority of EU-countries recorded positive GDP growth rates. Irish economy stood out with the highest growth rate in the whole observed period. On the other hand, there is a list of EU countries that recorded negative growth rates in the observed period: the Czech Republic (in 2013), Greece in 2013 and in 2015, Spain in 2013, Croatia in 2013 and 2014, Cyprus in 2013 and 2014, Italy in 2013, the Netherlands in 2013, Portugal in 2013, Slovenia in 2013 and Finland in 2013 and 2014.

The average unemployment rate for the EU economy in this period grew by $11 \%$ compared to the previous observed period (2008-2012). The economic crisis caused higher differences with respect to unemployment rate among EU countries, with the higher coefficient of variation compared to the previous period. The highest recorded average unemployment rate was 26\%, and was recorded in Spain.

Since 2015 was the record year for Germany with respect to net migration of 1.2 million people, and very high net migration in 2013 and 2014, and additionally decreasing unemployment rate, Germany was classified as a sole member of the first cluster, with the average net migration in the period 2013-2015 of 730 thousand people and the average unemployment rate of $5 \%$, the lowest in the EU.

France, Italy and the United Kingdom are again grouped together. Their average unemployment rate was relatively high, 9.6\% in the period 2013-2015. The average stock of foreign citizens was among the highest, of 4.7 million people. They recorded relatively high average GDP per capita of 29 thousand $€$ and relatively high 
The International Journal

ENTREPRENEURSHIP AND SUSTAINABILITY ISSUES

ISSN 2345-0282 (online) http://jssidoi.org/jesi/

2018 Volume 6 Number 2 (December)

http://doi.org/10.9770/jesi.2018.6.2(34)

average positive net migration of 170 thousand people. The United Kingdom's labour market can also commend with the third lowest unemployment rate in 2015, which was 5.3\%. The Czech Republic recorded the second lowest unemployment rate in 2015 of 5.1\%. Italy and France on the other hand recorded above average EU-28 unemployment rate in 2015, with the unemployment rate of $11.9 \%$ in Italy, and $10.4 \%$ in France.

One (the fifth) cluster consists again of the countries that have the highest GDP per capita, of 45.4 thousand $€$, and on average the lowest unemployment rate, of $4.6 \%$, below the EU-28 average: Austria, Belgium, Denmark, Finland, Ireland, Luxembourg, the Netherlands and Sweden. These countries attract foreign migrants and have positive net migration values of 44.6 thousand on average, and relatively high stock of foreign citizens, 670 thousand on average. The structure of this cluster is very similar to the pre-crisis period. There are some changes however. Cyprus left the cluster, since the global economic crisis seriously affected the Cyprus labour market, and the unemployment rate more than tripled in the period between 2006 and 2015. The unemployment rate was 4.6\% in 2006, and rose to 15\% in 2015 (although in 2013 and 2014 it was even higher, 16\%). Furthermore, the Cyprus economy was recording negative growth rates in the period between 2012 and 2014, especially in 2013, when it fell by 5.9\%. Consequently, since 2012 Cyprus economy became a net emigration country, with rising emigration and decreasing immigration levels.

The EU member states from Cluster 3: Bulgaria, Croatia, Cyprus, the Czech Republic, Estonia, Hungary, Latvia, Lithuania, Malta, Poland, Portugal, Romania, Slovakia and Slovenia, on average had the lowest GDP per capita, the lowest stock of foreign citizens averages, relatively high unemployment rate, and negative net migration values. The Czech Republic, Malta, Hungary, Estonia, Slovenia and Slovakia recorded positive net migration in 2015, whereas only in Slovakia, Malta and Hungary net migration was positive in the whole observed period between 2006 and 2015.

Spain and Greece were grouped in the same cluster, having on average, the highest negative net migration and the highest unemployment rate. These are EU countries with the relatively high level of income, and relatively high stock of foreign citizens.

\section{Conclusions}

In the observed period between 2006 and 2015, which also includes the period of global financial and economic crisis, European Union faced growing number and increasing share of foreign citizens, whose distribution with respect to hosting countries has changed as well. Especially volatile were migration flows. To make the analysis of economic and migration performances of European Union member states in the observed period more tractable, the cluster analysis was conducted based on the average values of the selected variables in four time periods. The gross domestic product (GDP) per capita was chosen as economic performance proxy, whereas the unemployment rate was used as the labour market performance indicator. The migration statistics indicators were represented by net migration as an indicator of migration flows, and stock of foreign citizens variable as an indicator of migration stock. The first period is the pre-crisis period, which includes years 2006 and 2007. The second is the period between 2008 and 2012, in which the EU economy struggled with the global economic and financial crisis. The third period refers to the recovery phase and includes years 2013 and 2014, and the final period is year 2015, the beginning of massive immigration in the EU area due to world migration crisis.

The cluster analysis identifies three clusters of countries in the pre-crisis and crisis periods. Cluster composed of the highest income EU countries with relatively low unemployment rate, positive relatively large net migration levels and relatively high stock of foreign citizens was relatively stable in the observed period. Austria, Denmark, Luxembourg, the Netherlands and Sweden were their constant members, whereas Belgium and Finland joined in the crisis and post-crisis period, mainly due to relatively higher unemployment rate in the pre-crisis period. 
Cyprus left it in the post-crisis period due to bad economic and labour market performances and consequently increasing negative net migration in the crisis period. Ireland was the only EU country that left the pre-crisis cluster in the crisis period and joined it again in the post-crisis period. The reason lies in negative GDP growth rates, sharp increase in unemployment rates and decreasing levels of immigration in the crisis period. Due to relatively good performances on the labour market in the crisis period, Slovenia and the Czech Republic joined this cluster in the crisis period, but left it in the post-crisis period.

Germany, France, Italy, Spain and United Kingdom shared the same cluster in the pre-crisis period. This cluser is composed of the economically strongest and the most attractive EU countries to migrants. These are countries with the highest stock of foreign citizens and relatively high average unemployment rate in the pre-crisis period. However, there were some major changes in the crisis and post-crisis periods. Spain left this cluster due to negative growth rates in the pre-crisis period and rising unemployment rates. Spain recorded large and increasing emigration levels, and decreasing immigration levels and consequently became net emigration country. On the other hand, Germany stood out with decreasing unemployment rates and very high net migration in post-crisis period, especially in 2015, being grouped in its own cluster in the post-crisis period.

The third cluser is mostly composed of countries that later joined the EU in the process of its enlargement. These are the lowest income EU countries, with the highest average unemployment rate, relatively low net migration levels in the pre-crisis period and negative and increasing net migration levels in crisis and post-crisis period. The average stock of foreign citizens was again the lowest among EU member states. The structure of this cluster was relatively stable, with Bulgaria, Croatia, Estonia, Hungary, Latvia, Lithuania, Poland, Portugal and Slovakia being its constant members, and Cyprus joining in the post-crisis period. Furthermore, Czech Republic, Slovenia and Malta joined this cluster in the pre-crisis and post-crisis period.

Spain and Greece were grouped in the same cluster in the post-crisis period, having on average, the highest negative net migration and the highest unemployment rate. These are EU countries with the relatively high level of income, and relatively high stock of foreign citizens.

The cluster analysis is based on the average values of the selected variables, which can be seen as a limitation of the research. Furthermore, it would be interested to conduct the sensitivity analysis of the k-means method with respect to the chosen variable values, since by taking averages in the period between 2013 and 2015 economically unreasonable results were obtained, grouping 20 EU-member states in the same cluster. 


\section{References}

Avlijas, S. 2017. Revisiting the Baltic growth model: From neoliberalism to the social investment welfare state, Sciences Po LIEPP Working Paper 66: 1-51. Retrieved from https://spire.sciencespo.fr/hdl:/2441/r04642f098es955171f7mo33i/resources/2017-wp66-sonjaavlijas-revisiting-the-baltic-growth.pdf

Aydemir, A.; \& Borjas, G. J. 2007. A Comparative Analysis of the Labor Market Impact of International Migration: Canada, Mexico, and the United States, Journal of the European Economic Association 5(4): 663-708. https://doi.org/10.1162/JEEA.2007.5.4.663

Beets, G.; \& Willekens, F. 2009. The Global Economic Crisis and International Migration: An Uncertain Outlook, Vienna Yearbook of Population Research 2009: 19-37. https://doi.org/10.1553/populationyearbook2009s19

Bodvarsson, O. B.; \& Van den Berg, H. 2013. The Economics of Immigration. New York: Published by Springer.

Bohle, D.; \& Greskovits, B. 2007. Neoliberalism, embedded neoliberalism and neocorporatism: Towards transnational capitalism in Central-Eastern Europe, West European Politics 30(3): 443-466. https://doi.org/10.1080/01402380701276287

Bora, D. J.; \& Gupta, A. K. 2014. Effect of Different Distance Measures on the Performance of K-Means Algorithm: An Experimental Study in Matlab, International Journal of Computer Science and Information Technologies 5(2): 2501-2506. Retrieved from http://www.ijcsit.com/docs/Volume\%205/vol5issue02/ijcsit20140502347.pdf

Borjas, G. J. 1999. The economic analysis of immigration, in Ashenfelter, O.; \& Card, D. (Eds). Handbook of Labor Economics. Elsevier, 1697-1760.

Chojnicki, X.; Edo, A.; \& Ragot, L. 2016. Intra-European Labor Migration in Crisis Times, CEPII Policy Brief 13: 1-16. Retrieved from http://www.cepii.fr/PDF PUB/pb/2016/pb2016-13.pdf

Clark, X.; Hatton, T. J.; \& Williamson, J. G. 2007. Explaining US immigration, 1971-1998, Review of Economics and Statistics 28: 359373. https://doi.org/10.1162/rest.89.2.359

Cuaresma, J. C.; Huber, P.; Oberdabernig; D. A.; \& Raggl, A. 2015. Migration in an ageing Europe: What are the challenges?, WWW for $\begin{array}{lllll}\text { Europe } \quad \text { Working } & \text { papers } & 1-41 . & \text { Retrieved from }\end{array}$ http://www.foreurope.eu/fileadmin/documents/pdf/Workingpapers/WWWforEurope WPS no079 MS17.pdf

Dąbrowski, P.; Fihel, A.; Kaczmarczyk, P.: \& Stefańska, R. 2014. Recent Trends in International Migration in Poland: The 2012 SOPEMI Report, Centre of Migration Research Working paper 71/129: 1-91. Retrieved from http://www.migracje.uw.edu.pl/wpcontent/uploads/2016/06/WP71129_2.pdf

De'ath, G.; \& Fabricius, K. E. 2000. Classification and regression trees: a powerful yet simple technique for ecological data analysis, Ecology 81: 3178-3192. https://doi.org/10.1890/0012-9658(2000)081[3178:CARTAP]2.0.CO;2

Dolnicar, S. 2002. A Review of Unquestioned Standards in Using Cluster Analysis for Data-driven Market Segmentation, University of Wollongong Archive, 1-9. Retrieved from https://ro.uow.edu.au/cgi/viewcontent.cgi?article=1286\&context=commpapers

Domínguez-Mujica, J.; Guerra-Talavera, R.; \& Parreño-Castellano, J. M. 2012. Migration to Spain Migration at a Time of Global Economic Crisis: The Situation in Spain, Central and Eastern European Migration Review 1(1): 69-90. https://doi.org/10.1111/imig.12023

European Commission. 2015. Standard Eurobarometer, 83: 1-44. Retrieved from http://ec.europa.eu/commfrontoffice/publicopinion/archives/eb/eb83/eb83_first_en.pdf

Eurostat. 2018a. Immigration by age, sex and broad group of citizenship. Retrieved from http://appsso.eurostat.ec.europa.eu/nui/show.do?dataset=migr_imm2ctz\&lang=en

Eurostat. 2018b. Emigration by age, sex and broad group of citizenship. Retrieved from http://appsso.eurostat.ec.europa.eu/nui/show.do?dataset=migr_emi1ctz\&lang=en 
Eurostat 2018c. Population on 1 January by age, sex and broad group of citizenship. Retrieved from http://appsso.eurostat.ec.europa.eu/nui/show.do?dataset=migr_pop2ctz\&lang=en

Eurostat 2018d. Total unemployment rate. Retrieved from https://ec.europa.eu/eurostat/tgm/table.do?tab=table\&init=1\&language=en\&pcode=tps00203\&plugin=1

Eurostat 2018e. Real GDP per capita. Retrieved from https://ec.europa.eu/eurostat/tgm/table.do?tab=table\&init=1\&language=en\&pcode=sdg_08_10\&plugin=1

Eurostat 2018f. Real GDP growth rate - volume. Retrieved fromhttps://ec.europa.eu/eurostat/tgm/table.do?tab=table\&init=1\&language=en\&pcode=tec00115\&plugin=1

Formann, A. K. 1984. Die Latent-Class-Analyse: Einführung in die Theorie und Anwendung. Weinheim: Published by Beltz.

Gradzewicz, M.; Growiec, J.; Kolasa, M.; Postek, L.; \& Strzelecki, P. 2014. Poland’s exceptional performance during the world economic crisis: New growth accounting evidence, NBP Working Papers 186: 1-57. Retrieved from https://www.nbp.pl/publikacje/materialy_i_studia/186_en.pdf

Hatton T. J.; \& Williamson, J. G. 2002. What Fundamentals Drive World Migration? NBER Working Papers 9159: 1-36. Retrieved from http://www.nber.org/papers/w9159.pdf

Hazans, M. 2016. Migration Experience of the Baltic Countries in the Context of. Economic Crisis, in Kahanec, M. and Klaus F. Zimmermann (eds). Labor Migration, EU Enlargement, and the Great Recession. Berlin-Heidelberg: Springer, 297-344.

Hicks, J. R. 1932. The theory of wages. London: Published by MacMillan.

Hille, H.; \& Straubhaar, T. 2001. The Impact of EU-Enlargement on Migration Movements and Economic Integration: Results of Recent Studies, in: OECD (Ed.). Migration Policies and EU-Enlargement. Paris, 79-100.

International Organization for Migration. 2017. World Migration Report 2018. 1-364. Retrieved from https://publications.iom.int/system/files/pdf/wmr_2018_en.pdf

Johnson, E. G. 1980. The labor market efects of immigration, Industrial and labor Relations Review 33(3): 331-341. Retrieved from https://www.jstor.org/stable/2522570

Kerr, S. P.; \& Kerr, W. R. 2011. Economic Impacts of Immigration: A Survey, Finnish Economic Papers 24(1): 1-32. Retrieved from http://taloustieteellinenyhdistys.fi/images/stories/fep/fep12011/fep12011_kerr_and_kerr.pdf

Lee, S. S.; \& Han, C. Y. 2012. Finding Good Initial Cluster Center by Using Maximum Average Distance, in Isahara, H.; and Kanzaki, K. (eds). Advances in Natural Language Processing, Lecture Notes in Computer Science. Berlin, Heidelberg: Springer, 228-238.

Lietuvnike, M. M.; Vasilis Vasiliauskas, A.; Vasilienè-Vasiliauskienė, V.; Sabaitytė, J. 2018. Peculiarities of illegal immigrant's intrusions into road freight transport units in the France - UK corridor, Entrepreneurship and Sustainability Issues 5(3): 634647. https://doi.org/10.9770/jesi.2018.5.3(16)

Lincényi, M. 2017. Entrepreneurship ecosystem facets: the European migrant crisis and public opinion in Slovakia, Entrepreneurship and Sustainability Issues 5(2): 357-367. https://doi.org/10.9770/jesi.2017.5.2(14)

Mayda, A. M. 2010. International Migration: A Panel Data Analysis of the Determinants of Bilateral Flows, Journal of Population Economics 23(4): 1249-1274. Retrieved from https://link.springer.com/content/pdf/10.1007\%2Fs00148-009-0251-x.pdf

Mohamad, I. B.; \& Usman, D. 2013. Standardization and Its Effects on K-Means Clustering Algorithm, Research Journal of Applied $\begin{array}{llllll}\text { Sciences, } & \text { Engineering } \quad \text { and } & \text { Technology } & \text { 3299-3303. }\end{array}$ https://pdfs.semanticscholar.org/1d35/2dd5f030589ecfe8910ab1cc0dd320bf600d.pdf 
Mooi, E.; \& Sarstedt, A. 2011. Concise Guide to Market Research. Berlin, Heidelberg: Published by Springer.

Nathan, M. 2014. The wider economic impacts of high-skilled migrants: a survey of the literature for receiving countries, IZA Journal of Migration 3(4): 1-20. https://doi.org/10.1186/2193-9039-3-4

Njaramba, J.; Chigeza, P.; Whitehouse, H. 2018. Barriers and challenges experienced by migrant African women entrepreneurs in North Queensland, Australia, Entrepreneurship and Sustainability Issues 5(4): 1054-1068. https://doi.org/10.9770/jesi.2018.5.4(25)

Stockhammer, E.; Durand, C.; \& List, L. 2016. European growth models and working class restructuring: An International post-Keynesian Political Economy perspective, Environment and Planning 48(9): 1804-1828. https://doi.org/10.1177/0308518X16646373

Süssmuth, R. 2009. The Future of Migration and Integration Policy in Germany. Washington, DC: Migration Policy Institute.

Thomassey, S.; \& Fiordaliso, A. 2006. A hybrid sales forecasting system based on clustering and decision trees, Decision Support Systems 42(1): 408-421. https://doi.org/10.1016/j.dss.2005.01.008

Tibshirani, R.; Walther, G.; \& Hastie, T. 2001. Estimating the number of clusters in a data set via the gap statistic, Royal Statistical Society, Series B (Statistical Methodology) 63(2): 411-423. https://doi.org/10.1111/1467-9868.00293

United Nations. 2017. International Migration Report 2017: Highlights. 1:38. Retrieved from http://www.un.org/en/development/desa/population/migration/publications/migrationreport/docs/MigrationReport2017_Highlights.pdf

\section{Appendix}

Table A1. Members of clusters for different observed periods, European Union member states by using two-letter country code

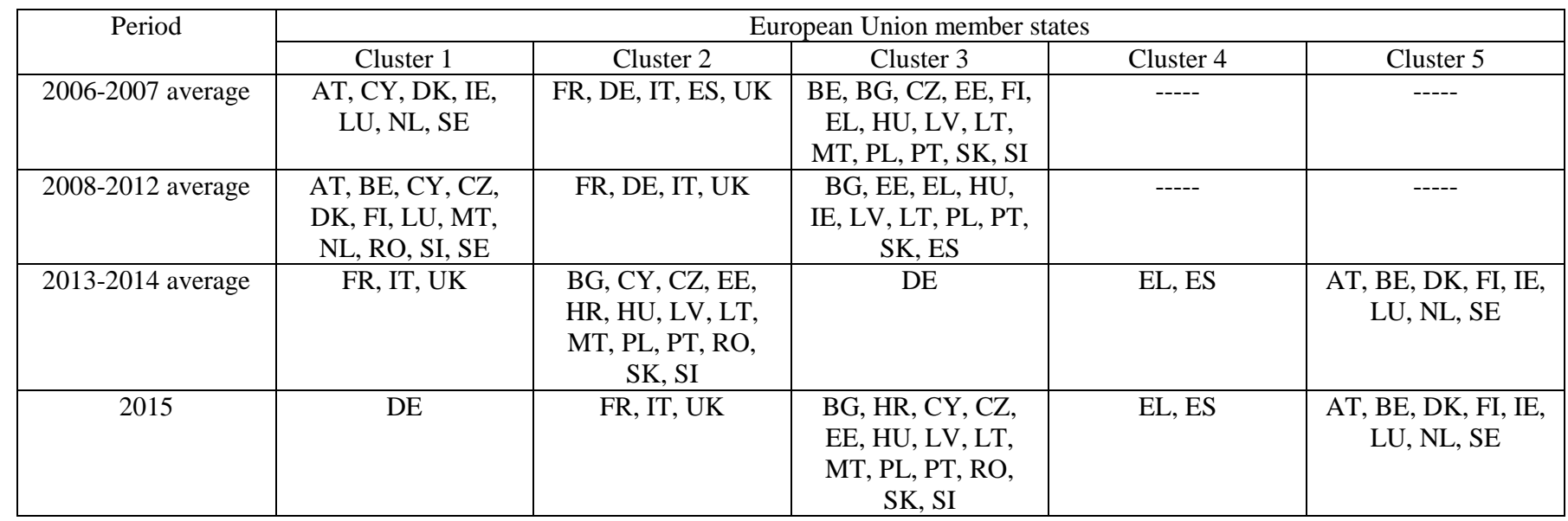

Source: Authors, Statistica 13.3 


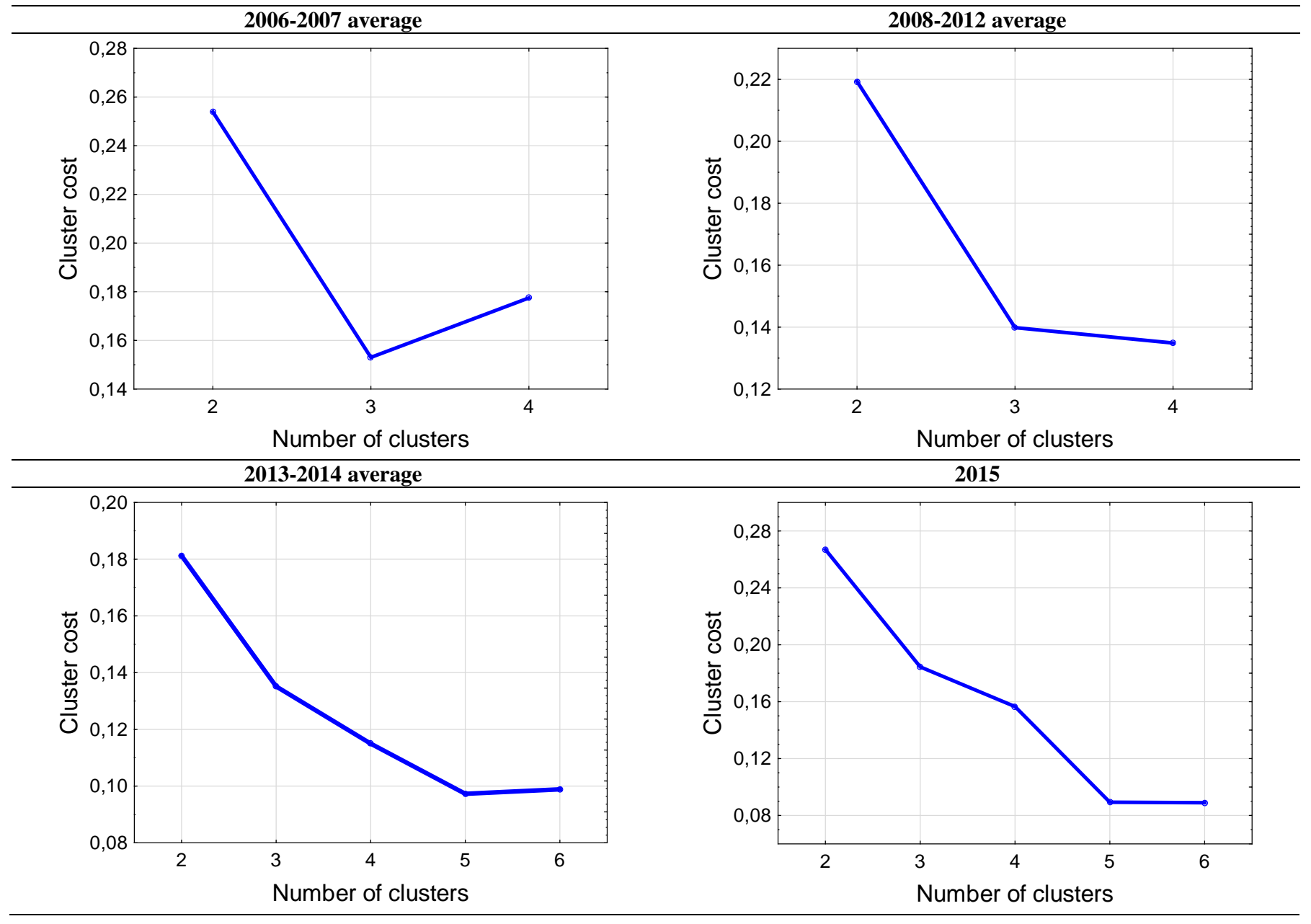

Fig. A1. Graphs of the cost sequence for different observed periods.

Source: Author's illustration, Statistica 13.3 


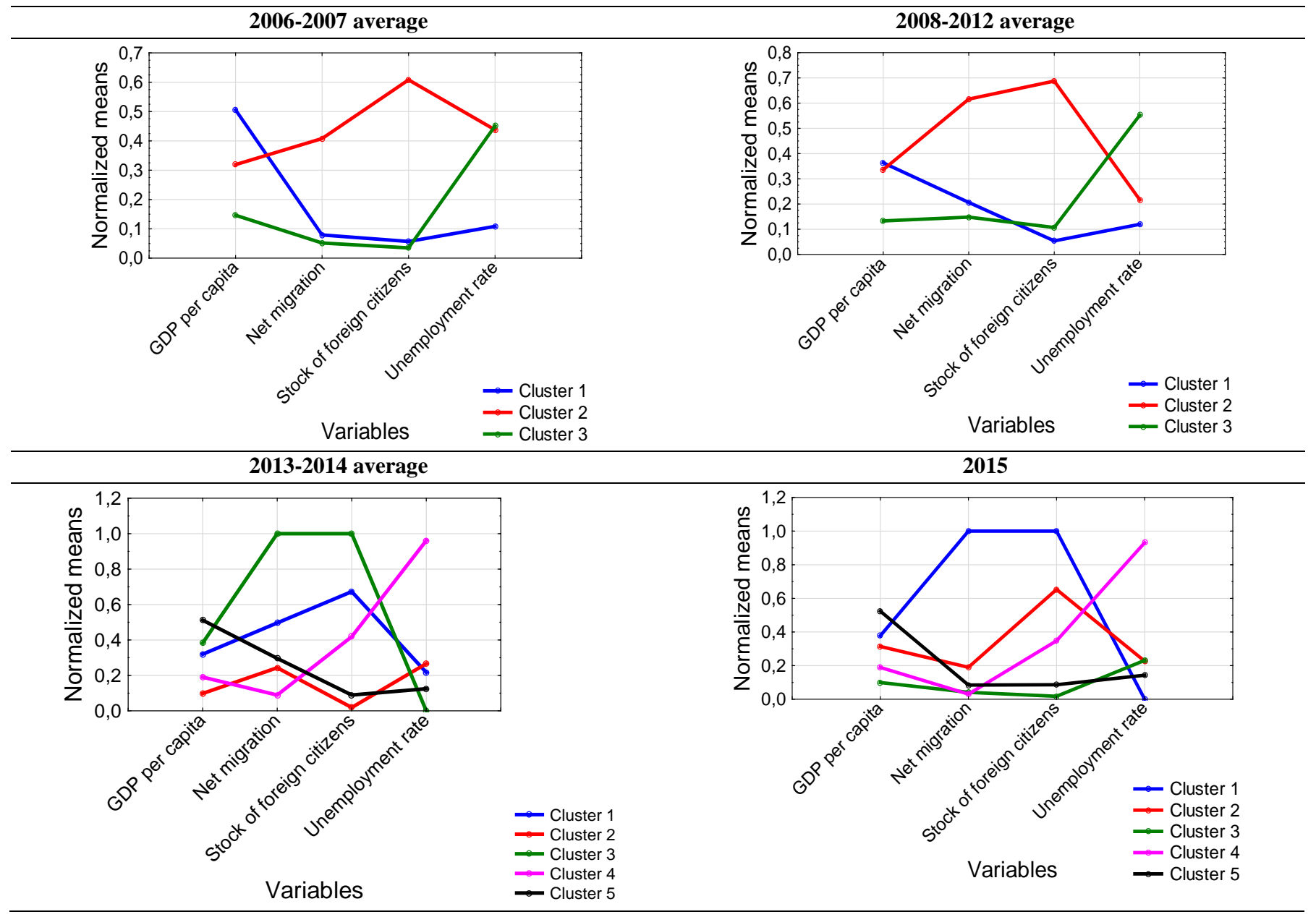

Fig. A2. Graphs of normalized means for different observed periods.

Source: Author's illustration, Statistica 13.3 
ENTREPRENEURSHIP AND SUSTAINABnational Journal

The International Journal
TAINABILITY ISSUES

ISSN 2345-0282 (online) http://jssidoi.org/jesi/

2018 Volume 6 Number 2 (December)

http://doi.org/10.9770/jesi.2018.6.2(34)

Lorena Škuflić is the Full Professor with tenure at the Department of Economic Theory, Faculty of Economics and Business, University of Zagreb, where she teaches multiple courses on the undergraduate, graduate and postgraduate (doctoral) study programmes related to economic theory and industrial organization. Her current research areas are trade integration, competitiveness, countries in transition and ICT sector. She is the (co) author of number of articles in international and national journals.

ORCID ID: https://orcid.org/0000-0002-2978-2902

Mira KRPAN is an Assistant Professor at the Department of Economic Theory, Faculty of Economics and Business, University of Zagreb, where she teaches Microeconomics and Principles of Economics. Her current research areas are mathematical modelling of economic phenomena and dual approaches to the optimization problems in microeconomic theory. She is the (co) author of number of articles in international and national journals.

ORCID ID: $\underline{\text { https://orcid.org/0000-0002-2574-0617 }}$

Berislav ŽMUK is an Assistant Professor at the Department of Statistics, Faculty of Economics and Business, University of Zagreb where he teaches following subjects: Statistics, Business Statistics and Business Forecasting. His main research fields include applications of statistics in business and economy, survey methodology and statistical quality control.

ORCID ID: https://orcid.org/0000-0003-3487-1376

Copyright (C) 2018 by author(s) and VsI Entrepreneurship and Sustainability Center

This work is licensed under the Creative Commons Attribution International License (CC BY).

http://creativecommons.org/licenses/by/4.0/ 
